\title{
Contributions of climate change on water resources in semi-arid areas; example of the Essaouira Basin (Morocco)
}

\author{
H. Chamchati and M. Bahir
}

\author{
Hydrogeology Laboratory, Dep. Geology, Faculty of Science Semlalia, Bd Prince My \\ Abdellah, BP 2390, Marrakech, Morocco
}

\begin{abstract}
The ground waters in semi-arid regions are subject to the impact of climatic and anthropogenic pressures. In the case of coastal aquifers, the vulnerability that arises is compounded by the risk of seawater intrusion. The joint application of several methodologies hydrodynamic and isotopic to the aquifer's coastal Essaouira basin in semi-arid region of Morocco has established a diagnosis of the current state of the aquifer and the risks it is submitted. This area includes two main superimposed aquifers. The Plio-Quaternary, which provides most of the water supply, is a reservoir is mostly sand, sandstone and conglomerates. Turonian calcareous dolomite is seeking recently by deep wells to supply drinking water to the city of Essaouira. The study area to form a syncline at heart Senonian is between two structures has diapiric Triassic material: the diapir Tidzi outcropping east and south and the cache of Essaouira diapir WEST, who was detected by the geophysics. In the Essaouira Basin, water resources are less important and are seriously affected by the climate in terms of quantity and quality, rainfall in the area does not exceed 300 $\mathrm{mm}$ year -1 on average, the average temperature hovers around $20^{\circ} \mathrm{C}$, potential evapotranspiration is very high, about $920 \mathrm{~mm}$ year -1 . The main direction of groundwater flow is from southeast to northwest toward the Atlantic Ocean. Essaouira basin is most vulnerable to climate drought since it is recharge is entirely dependent on rainwater. This finding should be incorporated into a management strategy directed towards safeguarding resources.
\end{abstract}

Keywords basin of Essaouira; aquifer; semi-arid regions; drought; hydro geochemistry; stable isotopes; recharge

\section{INTRODUCTION}

The relative scarcity of water resources in the basin of Essaouira their fragility and their unequal distribution give rise to a greater risk of shortage that is growing continually address climate change, population pressures and the growing needs of the socio-economic growth.

The aquifers are highly stretched, particularly those located on the coast. Some of them arrive at a stage of over-advanced. This led to a deterioration of chemical quality, indicated by the increase of salinity and locally by the real danger of seawater intrusion.

Essaouira synclinal area is semi-arid areas of Morocco (fig. 1) with very irregular rainfall not exceeding $300 \mathrm{~mm}$ year -1 on average. The average temperature hovers around $20^{\circ} \mathrm{C}$, the difference between the coldest month (January) and warmest month (August) can reach $17^{\circ} \mathrm{C}$ (Bahir, 2001). This sedimentary basin has an area of about $1200 \mathrm{~km} 2$ and is filled with Mesozoic and Cenozoic materials, which are overlaid with superficial Plio-quaternary terrains (Fig. 1). Low rainfall, it is variability and the significant recovery by evapotranspiration result in a water budget deficit. Thus, the water needs of this region, in the absence of a network of perennial surface important groundwater are the main source of supply for domestic needs and to a lesser extent for agriculture and industry.

In this area, the residents suffer from lack of water often aggravated by excessive periods of drought, which continued last 1991-92 to 1994-95 with annual rainfall below $200 \mathrm{~mm}$ on average.

This study aims to evaluate the potential water and set the behavior of the aquifer to climatic variations marked by a prolonged drought context. On the isotope, the objective is to study the modalities of functioning of aquifers Plio-Quaternary and Turonian and their possible relationships. 


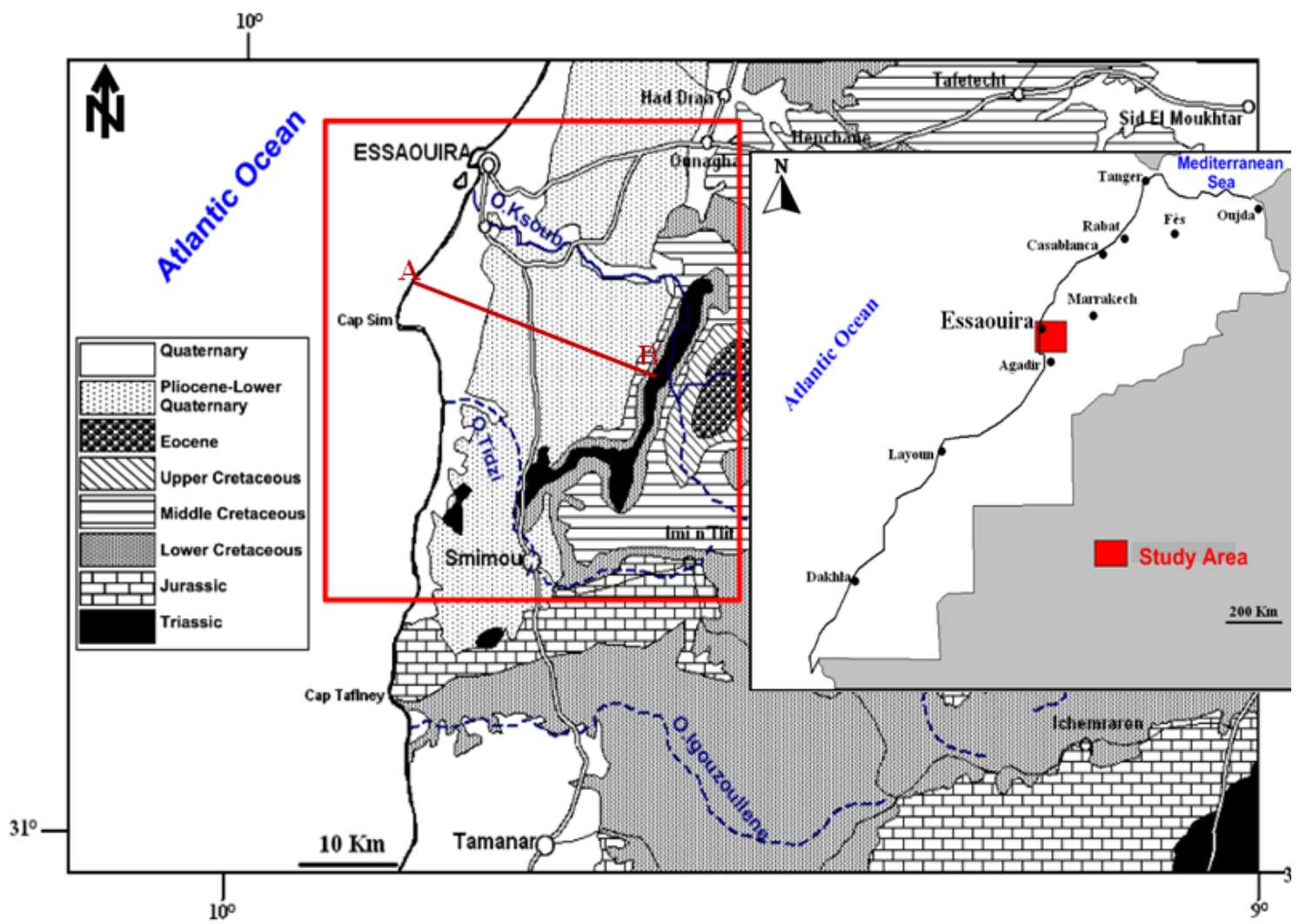

Fig. 1 Geological map (adapted from geological map of Morocco 1 / 1000000. 1985). A-B represents the cross-section location of Fig. 2.
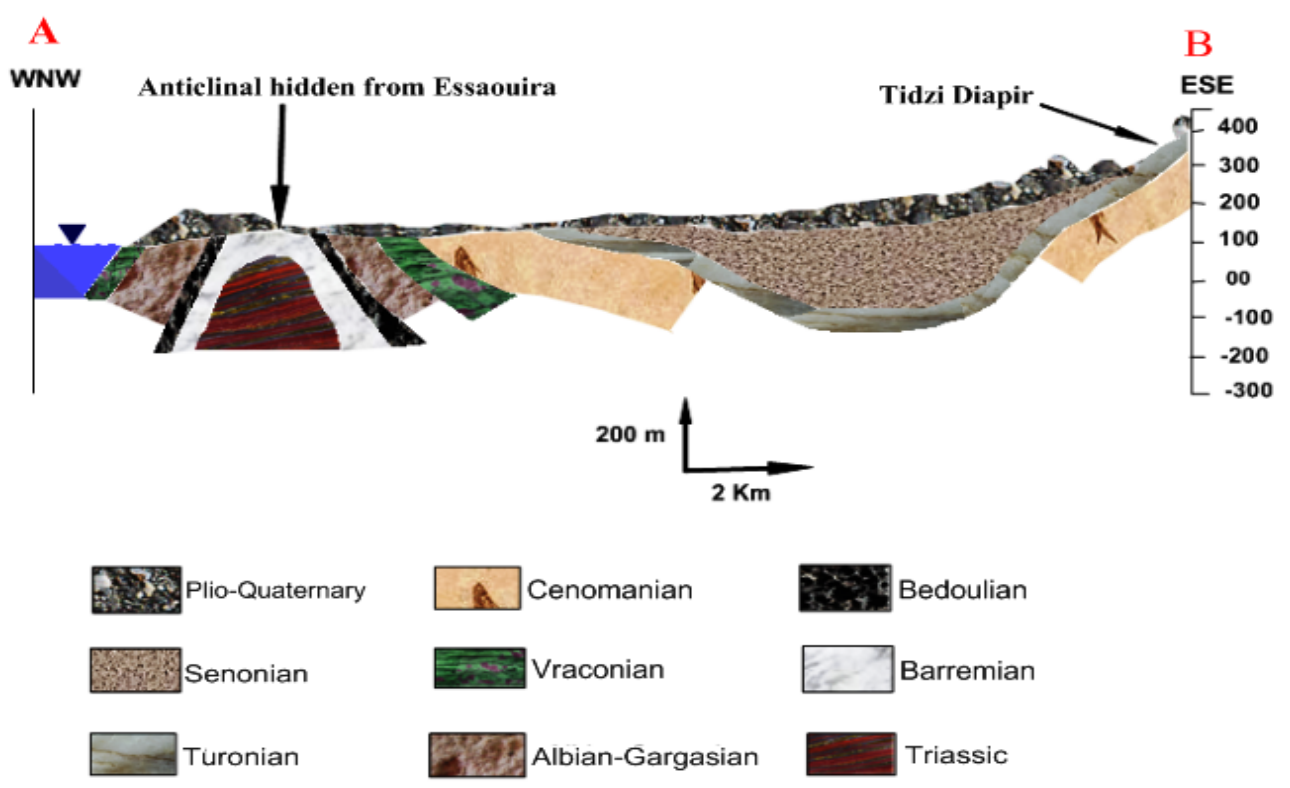

Fig. 2 Geological section of the syncline of Essaouira (after Fekri 1993, modified). For location, see Fig. 1, section AB. 
Geological and structural setting: In the Essaouira Basin, the main geological structures are represented in the east and south by the diaper Tidzi oriented NNE-SSW $(20 \mathrm{~km})$ from the Ksob wadi to Tidzi where he takes a direction $\mathrm{E}-\mathrm{W}$, in the west by the anticline heart Triassic of Essaouira, masked by the PlioQuaternary and recoveries identified by geophysics (fig. 2). Furthermore, intense fracturing branch N110 cutting Cretaceous carbonates formations. Essaouira synclinal area is less rugged terrain with a lower relief (Fig. 3) characterized by low hills, shaped by a sparse river system.

In this region, groundwater resources are contained in two main reservoirs: the Plio-Quaternary and Turonian. The Plio-Quaternary marine calcareous sandstone matrix or dune has a hydraulic conductivity primary porosity and contains a large free surface whose wall is formed in the synclinal structure, by the Senonian marls. It is operated in rural areas and ensures the supply of potable water for domestic purposes (Bahir et al, 2000) and a lesser extent irrigates farmland.

The Turonian contains a sheet quickly captivated by the Senonian marls in the synclinal structure and probably in direct contact with the Plio-Quaternary on the edges of this structure to the north to Ksob wadi, the West's approach Essaouira diapir hidden in the east and south near the Tidzi diapir. It has been requested since the late 80 s by deep wells that are primarily designed to meet the water needs of the city of Essaouira and some large villages.

\section{HYDROGEOLOGICAL SETTING}

The piezometric levels in the Essaouira multiaquifer present a general standardization through time (1990-2009) (Fig. 4). However, locally some piezometric variations can be identified. The aquifer is relatively shallow, and is consequently sensitive to drought, which can have a significant effect on water reserves. Periods of widespread drought have affected Morocco since 1978. Considered a semi-arid area with annual rainfall up to $300 \mathrm{~mm}$ year-1 and a very high potential evapotranspiration of about 920 mm year-1 (Agoumi, 1999; Hassani et al., 1998).

However they are characterized by high spatial and temporal variability. Thus the annual rainfall varies from 100-630 mm (Fig. 5a) and precipitation of rain within one year shows two seasons, dry from April to September and wet from November to March (Fig. $5 b)$.

The main flow direction is from SE to NW towards the Atlantic Ocean, being the recharge area located near the Tidzi diapir (Fig. 4). The piezometric maps, since 1990 to 2009, show, in the N, a line deviation to the $\mathrm{NE}$, indicating a possible contribution of the wadi in the aquifer recharge.

Differential gauging towers made of the hydrological cycle 1990-1991 were used to estimate the flows from a undercover Ksob wadi to Plio-Quaternary aquifer at $42 \mathrm{~L} \mathrm{~s}^{-1}$ (Fekri, 1993). The portion of the river in the gorge where the Turonian outcrops would result from the same author in losses of $64 \mathrm{~L} \mathrm{~s}^{-1}$ in favour of Turonian aquifer.

\section{ISOTOPIC COMPOSITION}

In these conditions and to understand better the functioning of these aquifers and therefore despite the contribution of geological studies carried out in the basin, a combined approach between the methods of hydrodynamic and isotope geochemistry has been followed for many years. It is identified the origin of groundwater and to locate areas of natural recharge and the links between groundwater (seepage exchanges), contribution to explaining the origin of the mineralization, especially in sectors the saltier.

In the Essaouira Basin, the hydrodynamic behaviour is strongly influenced by runoff (CHKIR, N et al., 2008). In this context, stable isotopes are a tool performs to determine the origin and history of water recharge areas and relations between the layers. Samples collected throughout the basin in October 2006 (Figure 6). Analyses were performed at the Technological Institute of Lisbon Sacavem Department of Environmental and Analytical Chemistry in the context of the Integrated Action between the universities of Lisbon and Marrakesh and funded jointly; the results of these tests are grouped in Table 1.

In the Essaouira Basin, the isotope content of water Plio-Quaternary is between -3.72 and $-4.56 \%$ vs. d180 SMOW. These waters are the cloth Turonian between -4.17 and $-4.55 \%$ vs. d180 SMOW 


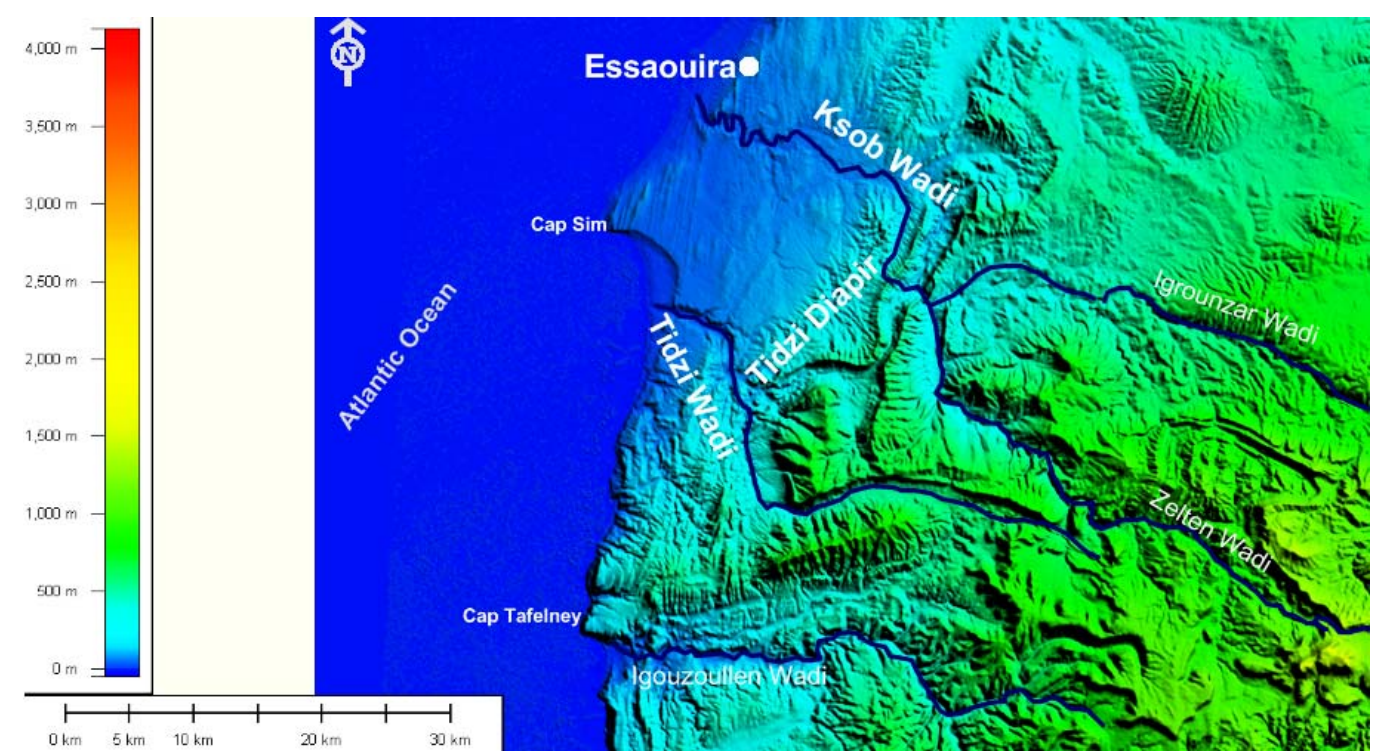

Fig. 3 MNT map of the study area.
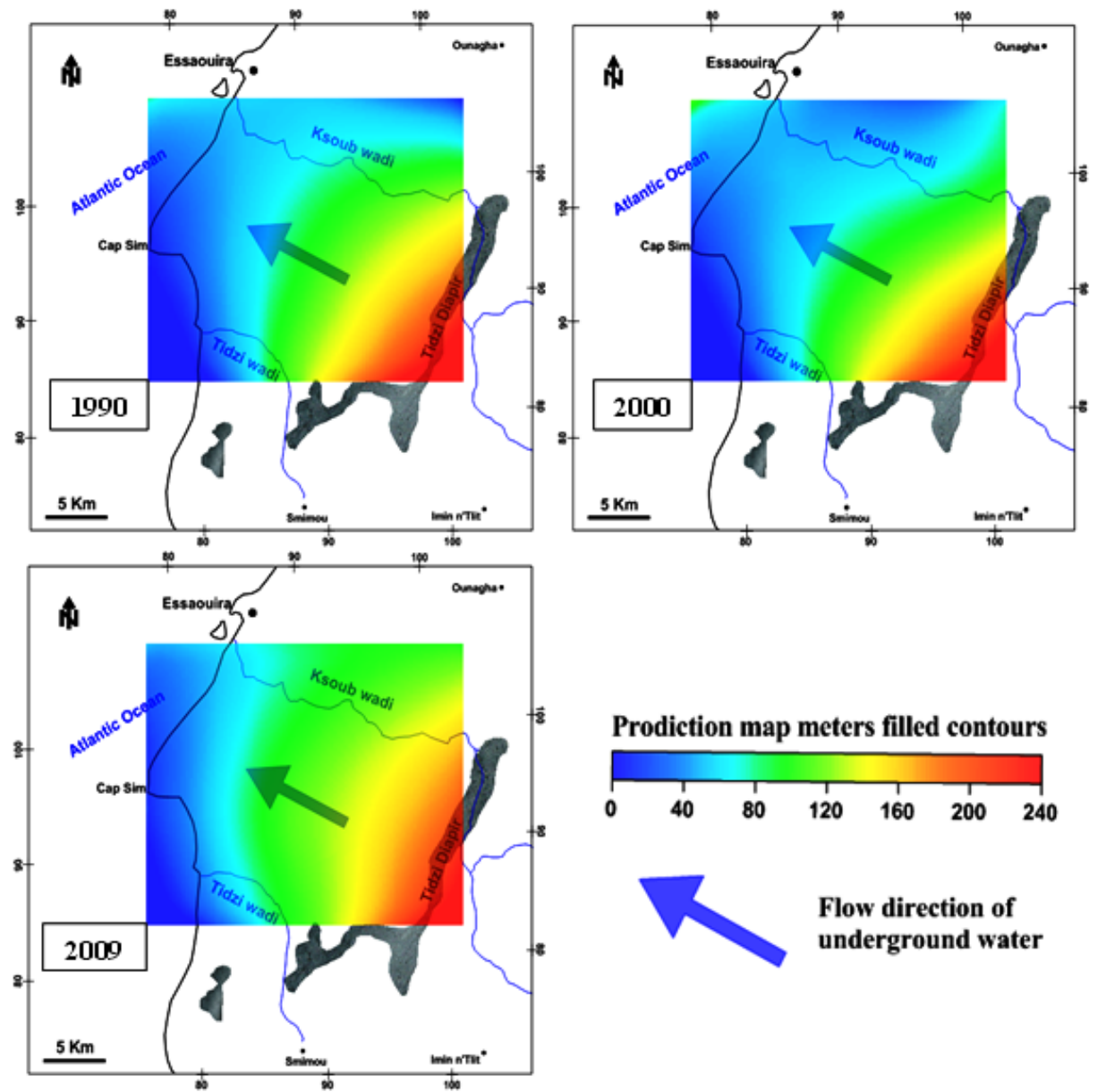

Prodiction map meters filled contours

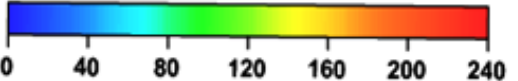

Fig. 4 Essaouira basin piezometric map through time: 1990, 2000 and 2009. 

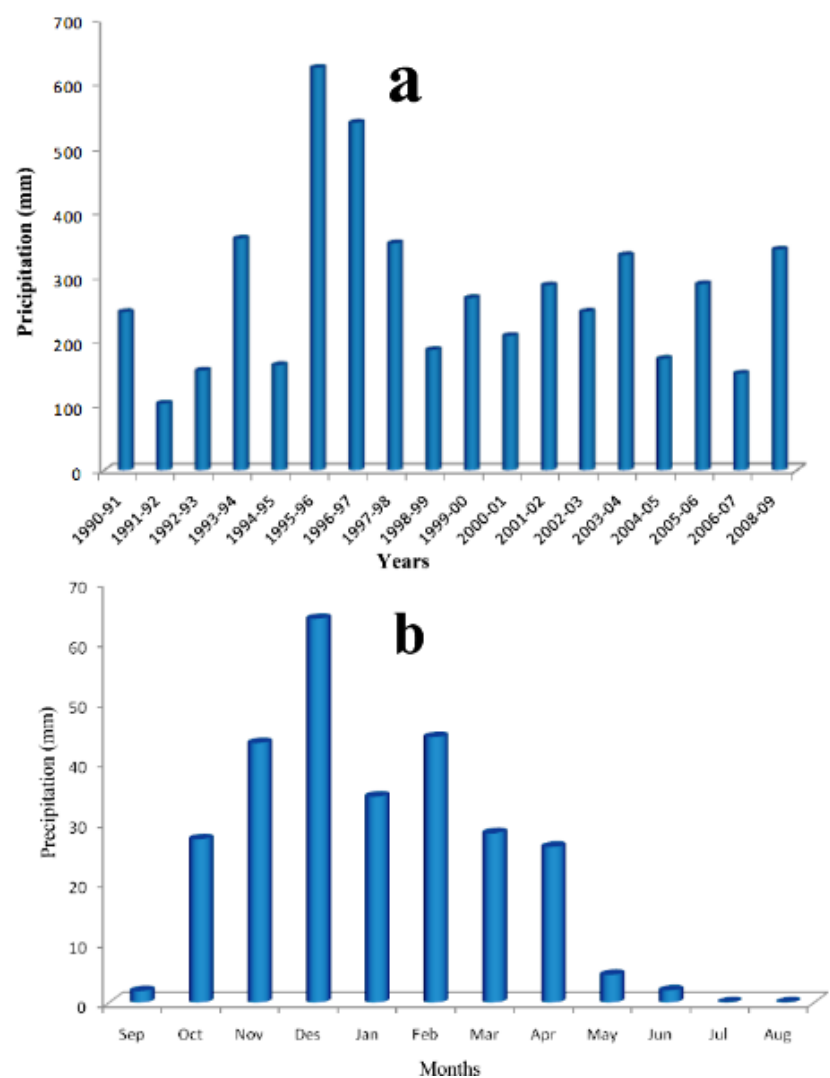

Fig. 5 Precipitation (a) annual values and (b) monthly mean values at Essaouira Station (1990-91 to 2008-09).

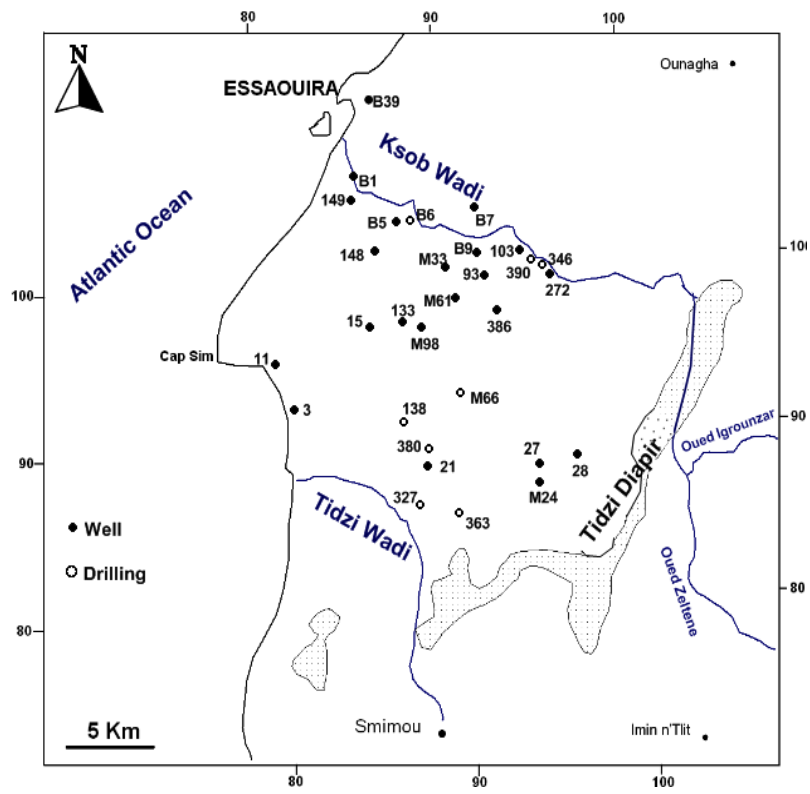

Fig. 6 Distribution of sampled water points in the study area. 
Am. J. Sci. Ind. Res., 2011, 2(2): 209-215

Tab. 1 Contents of stable isotopes ${ }^{18} \mathrm{O}$ and ${ }^{2} \mathrm{H}$ of the waters of Essaouira synclinal (companion of October 2006)

\begin{tabular}{cccccc}
\hline Sample & $\mathrm{X}$ & $\mathrm{Y}$ & $\mathrm{d}^{18} \mathrm{O}(\%)$ & $\mathrm{d}^{2} \mathrm{H}$ & Aquifer \\
\hline B2=149-51 & 85,1 & 105,8 & -3.79 & -19.2 & Plio-Quat \\
\hline $386-51$ & 92 & 98,65 & -4.17 & -22.2 & Turonian \\
\hline M98 & 89 & 100 & -4.56 & -24.2 & Plio-Quat \\
\hline B17=15-51 & 86 & 97 & -3.87 & -19.3 & Plio-Quat \\
\hline 11-51 & 80,45 & 96,45 & -3.50 & -14.9 & Plio-Quat \\
\hline B20=21-51 & 89,4 & 91,4 & -4.51 & -26.2 & Plio-Quat \\
\hline B21=380-51 & 89,35 & 91,8 & -4.56 & -23.6 & Plio-Quat \\
\hline B23=363-51 & 89,75 & 88,2 & -4.55 & -26.8 & Turonian \\
\hline B22=327-51 & 88,8 & 88,8 & -4.11 & -21.3 & Plio-Quat \\
\hline $27-51$ & 95,5 & 91,3 & -4.55 & -22.9 & Plio-Quat \\
\hline M24 & 95 & 91,5 & -4.34 & -23.5 & Plio-Quat \\
\hline 28-51 & 97,2 & 91,8 & -4.50 & -22.7 & Plio-Quat \\
\hline $148-51$ & 85,7 & 102,05 & -3.82 & -20.7 & Plio-Quat \\
\hline Ksob Wadi & 86 & 106 & -3.57 & -19.0 & Plio-Quat \\
\hline 93-51 & 92,37 & 101,9 & -4.33 & -22.3 & Plio-Quat \\
\hline B12=390-51 & 97 & 100 & -4.37 & -25.8 & Turonian \\
\hline B13=272-51 & 97,17 & 100,76 & -3.72 & -20.3 & Plio-Quat \\
\hline B14=346-51 & 97,25 & 100,7 & -4.17 & -21.4 & Turonian \\
\hline
\end{tabular}

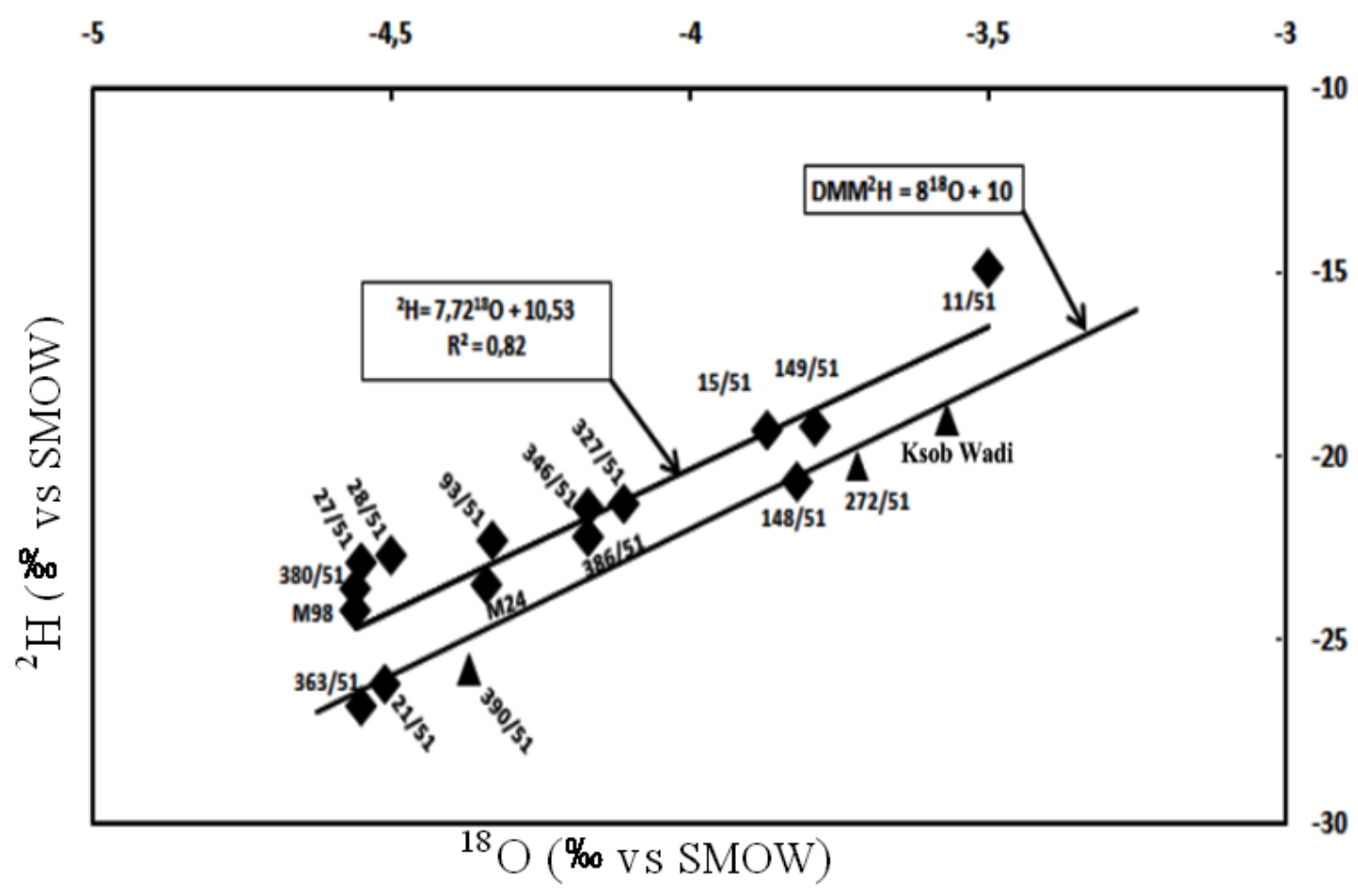

Fig. 7 Relationship ${ }^{18} \mathrm{O}$ - deuterium the groundwater in the area of Essaouira synclinal. 
The correlation diagram for deuterium vs. oxygen-18 water in the basin of Essaouira can define a local meteoric right equation: $d=7.722 \mathrm{H} 180+10.53(\mathrm{n}$ $=15, \mathrm{R} 2=0.82$ ) bit different from the global meteoric water (DMM) slope 8 with a deuterium excess around 10.

It characterizes the precipitation of oceanic origin; the equation of this line was calculated without taking into account the three water points 390-51, 272-51 and Ksob wadi identified as evaporated because they are placed below right meteoric (Figure 7).

The point marked by 272-51 evaporation PlioQuaternary aquifer and is in close proximity to the river, which confirms the power of the water in the Ksob wadi already highlighted in a quarter Northeastern sector of the aquifer piezometer. Well 39051, which captures the Turonian aquifer, it is position on the diagram ${ }^{18} \mathrm{O}$-deuterium indicates complementary evaporated water from the river for part of the low water. The other water analyzed aligned right meteoric which means that the power of the two aquifers, and especially of the Turonian aquifer is rapid evaporation without significant if we exclude the point 390-51.

\section{CONCLUSIONS}

The supply of drinking water for the city of Essaouira and the surrounding rural settlements is based mainly on groundwater, including those of the water PlioQuaternary. The latter is subject to several constraints. Shallow, it is both highly sensitive to droughts, which are widespread in Morocco, the worst of the 1995 whose effects are still felt.

This indicates a risk of water shortage in the short term for the city of Essaouira, especially since the recharge rate is lower for the Turonian deep water. However, if the context of drought years back, as revealed in the current global trend, the government will have no other alternatives as the use of unconventional resources such as desalinated seawater for drinking water or treated wastewater for agriculture must be currently considered as a priority in order to avoid triggering shortages of water. The development of a strategy could enable rational exploitation of it is waters enhance it is potential while safeguarding long-term.

\section{REFERENCES}

Agoumi A (1999) Introduction a` la problématique des changements climatiques (Introduction to the climate changes problem). Projet magrébin sur les changements climatiques RAB/94/G31: SOMIGRAF, $p$ 98.

Bahir, M., Jalal, M., Mennani, A. (2001). Pollution nitratée des eaux souterraines du bassin synclinal d'Essaouira.(Groundwater pollution by nitrates of the Essaouira synclinal basin). J. Environ. Hydrol., Paper 18, Vol. 9.

Bahir, M., Mennani, A., Jalal, M., Youbi, N. (2000). Contribution à l'étude des ressources hydriques du bassin synclinal d'Essaouira (Maroc). Estudios Geol.,56: 185-195.

Bahir, M., Jalal, M., Mennani, A., Fekri, A. (1999). Contribution à l'étude hydrogéologique et hydrochimique de la zone synclinale d'Essaouira (Contribution to the study of the hydrogeology and hydrochemistry of the Essaouira synclinal area). Congrès Intern. sur l'eau et la désertification. Le Caire.

Chkir, N. ; Trabelsi, R. ; Bahir, M. ; Hadji Ammar, F. ; Zouaei, K. ; Chamchati, H.\& Monteiro, J.P. (2008). Vulnérabilité des ressources en eau des aquifères côtiéres en zones semi-arides-etude comparative entre les bassin d'Essaouira (Maroc) et la Jeffara (Tunisie). Comunicaçoes Geologicas.; t.95,pp.107121.

Fekri, A. (1993). Contribution à l'étude hydrogéologique et hydrogéochimique de la zone synclinale d'Essaouira (Bassin synclinal d'Essaouira). 3rd cycle dissert.

Galego Fernandes, P. ; Bahir, M. ; Mendoca, J. ; Carreira, P. ; Fakir, Y. \& Silva, M.O. (2005). Anthropogenic feactures in the Sines (Portugal) ans Essaouira (Maroc) coasltal aquiferes: a comparative study of their hydrochemical evolution by a principal component analysis. Estudios Géol., 61: 207-219.

Galego Fernandes, P.; Carreira, M., P.; Bahir, M. (2010) Mass balance simulation and principal components analysis applied to groundwater resources : Essaouira basin (Morocco). Journal of Environ earth Sci (2010) 59:1475-1484. 